\title{
Fracture Mechanical Analysis of Gleeble Simulated Heat Affected Zones in High Strength Steels
}

\author{
Zsuzsanna Koncsik ${ }^{1 *}$ János Lukács ${ }^{1}$ †Gyula Nagy¹ \\ ${ }^{1}$ Institute of Materials Science and Informatics, Faculty of Mechanical Engineering and Informatics, University of Miskolc, H-3515 \\ Miskolc-Egyetemváros, Hungary \\ * Corresponding author, e-mail: zsuzsanna.koncsik@uni-miskolc.hu
}

Received: 13 August 2021, Accepted: 17 November 2021, Published online: 01 December 2021

\begin{abstract}
During the research work the fracture mechanical investigation of heat affected zones of thermomechanical rolled high strength steels (Voestalpine Alform 960M) were carried out. For production of appropriate heat affected zones Gleeble 3500 physical simulator was applied, with different heating cycles and specific cooling times. Following the simulation, fracture mechanical investigations were performed, in favor of determination crack tip opening displacement (CTOD or $\delta$ ) values.
\end{abstract}

Keywords

Gleeble simulation, heat affected zones, fracture mechanics, CTOD

\section{Introduction}

The application of the modern high strength steels obtains an important role in different sectors of industry, especially in automotive industry. In such cases, the thickness of the structural elements can be decreased together with the mass of the structure and the welded joints [1-3]. Directly and indirectly the emission of greenhouse gases can also be decreased [4]. In general, we can state that with the increasing of the yield strength, the applied thickness can be decreased, so the amount of the filler metal and the time of the welding decrease, as well. The most effective way of strength increasing is the decreasing of grain sizes. In the 1970 years a new process, called thermomechanical rolling was developed to achieve outstanding strength and advanced weldability properties. In this case the yield strength can be increased without changes in chemical composition, only by selection the appropriate rolling parameters. The developments on the field of steel production as well as on rolling and application are still undiminished [5-7].

On a different point of view, it is important to note, that high strength steels often contain material discontinuities, e.g. cracks or crack like defects, and their behavior under different loading conditions can be predicted only by fracture mechanical data. Not only the base material, but the welded microstructure is also important for a designer. In many cases it is impossible to investigate certain heat affected zones (HAZs) of a real welded joint, because during the real process the thermal gradient is so high in the material, that strong inhomogeneous microstructure occurs, which is changing per $0.1 \mathrm{~mm}$. Applying physical simulation [8] homogeneous samples in high amount can be prepared, aimed to following mechanical tests, like impact toughness test, fracture toughness and microstructural analyses $[9,10]$.

The advanced high strength steels have further advantages, they show high toughness values as well. Due to this behavior the common fracture toughness parameter (the valid $K_{I C}$ ) is not possible to measure, to evaluate. For this reason, in the HAZ and according to the valid standard ISO 12135:2016 [11], the evaluation of crack tip opening displacement (CTOD or $\delta$ ) becomes conspicuous.

The investigation results published in this paper fit to a larger research topic, in which the focus is on changes of toughness in HAZ during welding [12-20]. The longterm aim of this research is the fracture mechanical analyses of HAZs created by physical simulation. The previous weld-technological research [21-23] has been proved significant impact energy reduction in less tough HAZs on the S960M materials grade [24-27]. Therefore, as the first step fracture mechanical investigations were carried out on base material at room and at low temperatures. 
The next step of the research work, presented in this paper is the analyses and evaluation of the fracture mechanical properties, CTOD fracture toughness of Gleeble simulated heat affected zones (HAZs) of S960M thermomechanical rolled high strength steel (Voestalpine ALFORM 960M).

\section{Materials and methods}

\subsection{Investigated samples}

A $15 \mathrm{~mm}$ thick plate was selected as base material for the physical simulation experiments. A precise preparation of HAZ specimen is needed with required geometrical shape of $10 \times 10 \times 70 \mathrm{~mm}$ and appropriate surface quality aiming for accurate crack detection. The chemical composition of the investigated S960M samples is shown in Table 1.

According to the certificate of Voestalpine the room temperature tensile properties of the investigated samples are as follows: $Y S=1051 \mathrm{MPa}, T S=1058 \mathrm{MPa}$, and $A_{5}=17 \%$ [28]. Our own control measurement showed different value for the yield strength: $Y S=958 \mathrm{MPa}$, and the measured Youngs-modulus is 195 GPa. During the evaluation of the fracture mechanical investigation results the measured values were applied.

\subsection{Simulation circumstances}

HAZ tests [29] were performed in a new generation of thermomechanical simulator, Gleeble 3500 [29-31], which is capable for the reproduction of real material processing (e. g., welding, heat treatment and metal forming) in laboratory circumstances. For temperature measurements K-type thermocouple ( $\mathrm{NiCr}-\mathrm{Ni}$ ) was applied which was welded onto the middle of specimen for temperature record and control by means of the induction heating.

The maximum temperature, holding time and cooling rate of the thermal cycle parameters were selected based on the possible procedures during the gas metal arc welding (GMAW). Heat cycles were determined according to the Rykalin 3D model [32], where the whole heat cycle, including heated part as well, was described by time-temperature points instead of automatic software settings. In order to simulate the HAZ area, with the lowest toughness

Table 1 Chemical composition of investigated samples according to certificate, in $\mathrm{wt}^{\%} \%$ [28]

\begin{tabular}{cccccccc}
\hline $\mathrm{C}$ & $\mathrm{Si}$ & $\mathrm{Mn}$ & $\mathrm{P}$ & $\mathrm{S}$ & $\mathrm{Cr}$ & $\mathrm{Ni}$ & $\mathrm{Mo}$ \\
0.14 & 0.30 & 1.13 & 0.007 & 0.001 & 0.3 & 0.04 & 0.167 \\
$\mathrm{~V}$ & $\mathrm{Ti}$ & $\mathrm{Cu}$ & $\mathrm{Al}$ & $\mathrm{Nb}$ & $\mathrm{B}$ & $\mathrm{N}$ & - \\
0.011 & 0.003 & 0.01 & 0.034 & 0.001 & 0.002 & 0.003 & - \\
\hline
\end{tabular}

(CGHAZ $=$ coarse grained HAZ), specimens were heated up to $1350{ }^{\circ} \mathrm{C}$ and cooled down to room temperature with different cooling time, $5 \mathrm{~s}, 15 \mathrm{~s}, 30 \mathrm{~s}$. Furthermore, specimens were created with the same parameters, in addition with a second heating cycle at $775{ }^{\circ} \mathrm{C}$ aiming to create ICGHAZ (intercritical coarse grained HAZ) zone. The heating models of the simulations are given in Fig. 1.

The experimental work was carried out on 4 specimens for each variant, applying 6 different simulation parameters altogether 24 specimens were prepared. From every testing variant 3 specimens were meant for fracture toughness test, and 1 specimen for microstructural analyses and hardness tests to control the efficiency of simulation. Two different microstructures of simulated specimens are shown in Fig. 2. The upper part of the figure shows finer grain sized microstructure resulting from fast cooling, while the lower part shows larger grain size from double heating cycle and slow cooling. Applying double heating cycle the grain boundaries are more explicit.

As further control of the simulation process, HV1 hardness values were also measured on the specimens. A mean hardness value of $340 \mathrm{HV} 1$ (standard deviation coefficient: $3.3 \%$ ) was measured for specimens with $5 \mathrm{~s}$ cooling
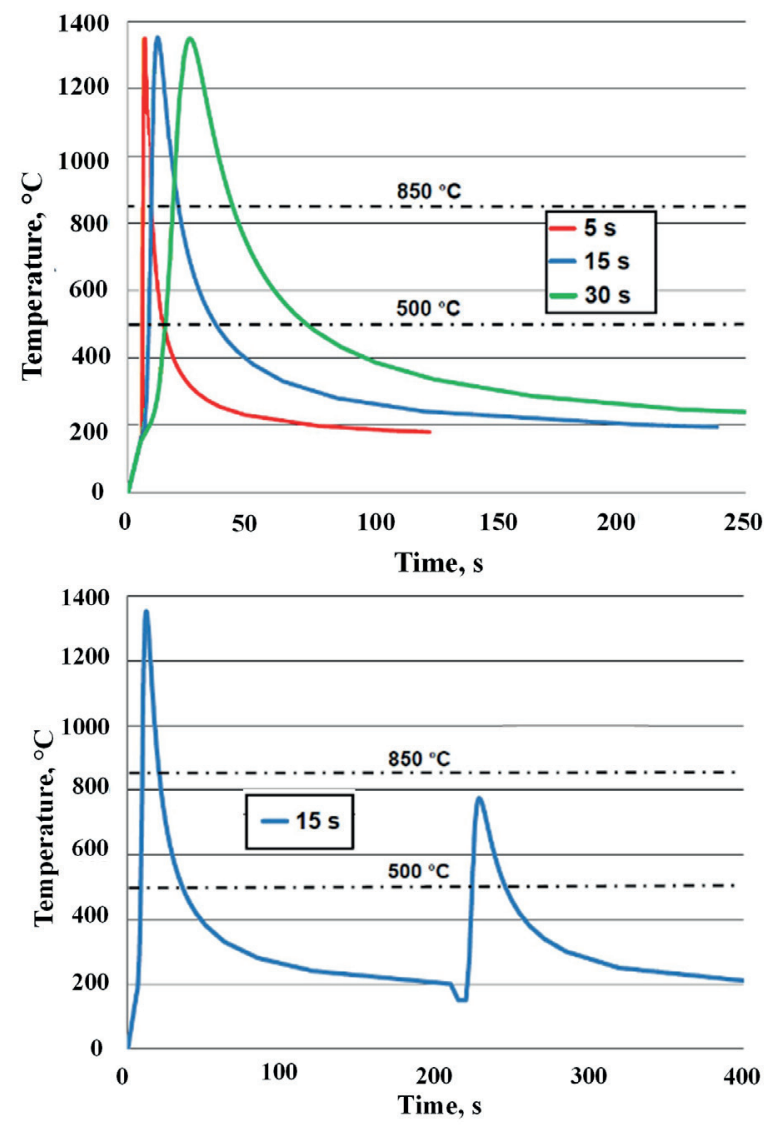

Fig. 1 Heating models for Gleeble simulation 

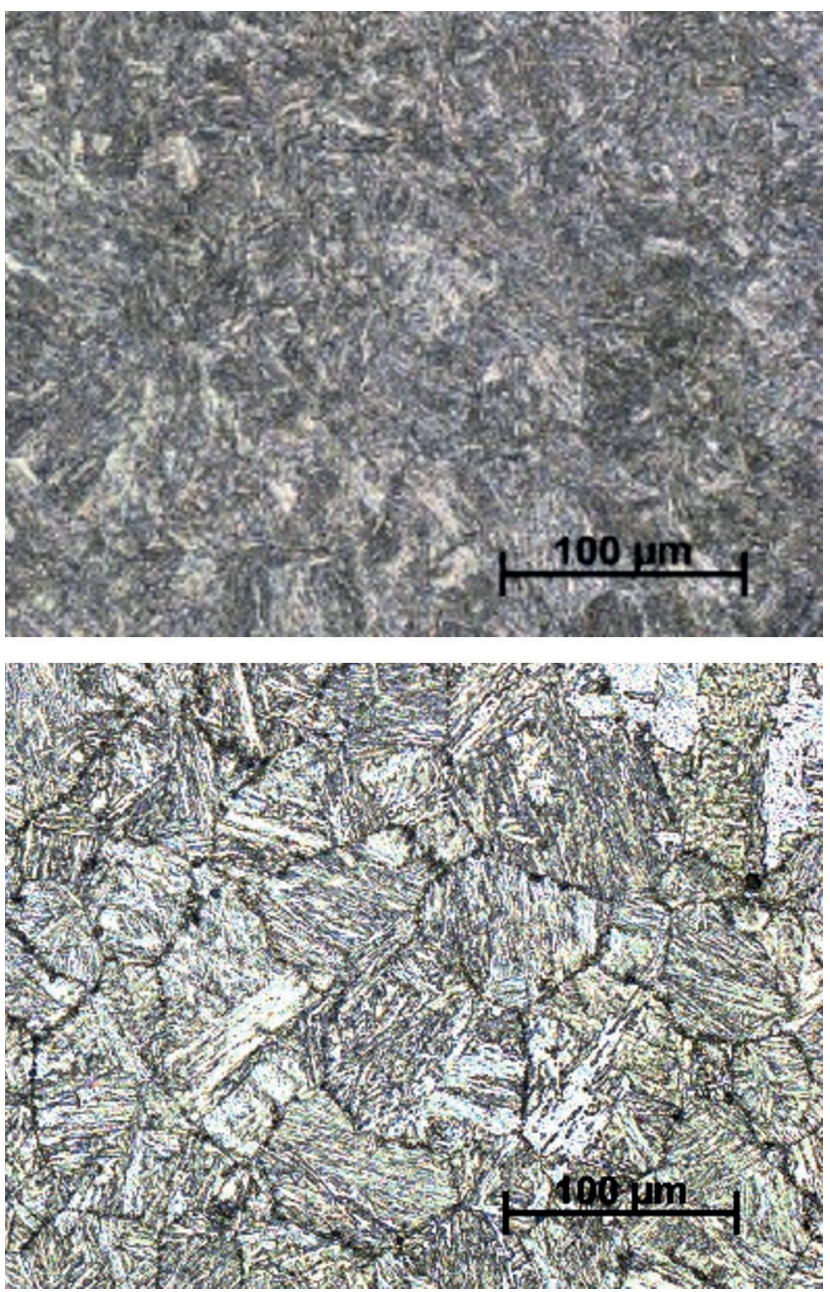

Fig. 2 Microstructure of the specimens, above: $T_{\text {peak }}=1350{ }^{\circ} \mathrm{C}$, $t_{8.5 / 5}=5 \mathrm{~s}$, below: $T_{\text {peak }}=1350+775^{\circ} \mathrm{C}, t_{8.5 / 5}=30 \mathrm{~s}$ cooling time

rate and a mean value of $273 \mathrm{HV} 1$ (standard deviation coefficient: $2.3 \%$ ) was measured for specimens with $30 \mathrm{~s}$ cooling rate.

\subsection{Fatigue precracking procedure}

After simulation, the 18 specimens were prepared for the fracture mechanical test. Chevron notch, see Fig. 3, was machined in each specimen, in the HAZs.

The specimens were fatigue precracked, according to the ISO 12135 [11] standard, with a maximum force of $3160 \mathrm{~N}$ in 9-14 steps, until the precrack length reached $1.3 \ldots 1.5 \mathrm{~mm}$ on the surface. The crack propagation on the surface was observed with a digital camera.

\subsection{Three-point bending tests}

Three-point bending tests were carried out on universal mechanical testing machine MTS 810.2, at room temperature.
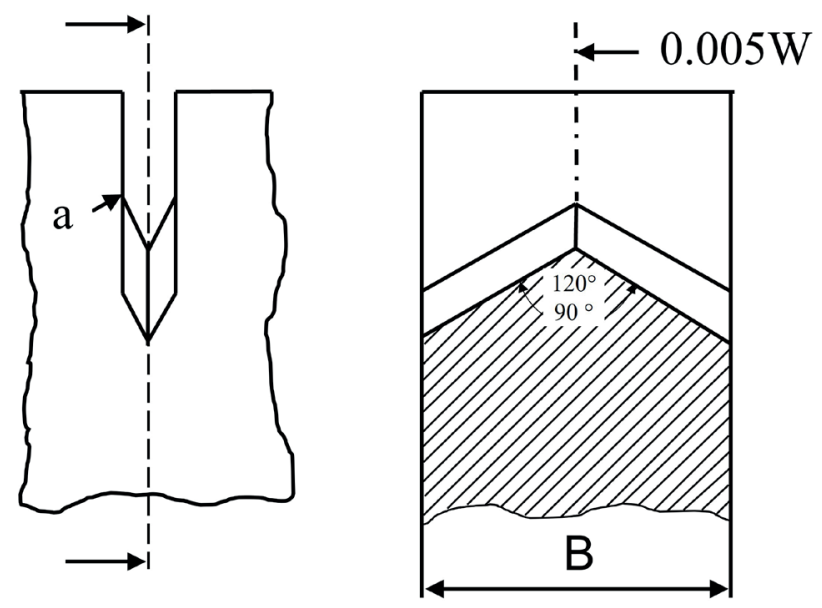

Fig. 3 Chevron notch geometry applied for the simulated specimens ( $a=$ crack length, $B=$ specimen thickness, $W=$ specimen width)

The adjusted experimental circumstances are:

- applied load: static increasing;

- applied velocity: $0.05 \mathrm{~mm} / \mathrm{s}$;

- lower support and upper bending radius: $5 \mathrm{~mm}$;

- span: $40 \mathrm{~mm}$.

The crack tip opening displacement was measured by a strain gauge type MTS $632.02 \mathrm{C}$ attached to a clip placed between two accurately positioned knife edges at the mouth of the machined notch, applied with measurement range of $\pm 1.5 \mathrm{~mm}$.

For the investigation, own developed program was applied in the frame program of MTS TestWare, the controlled variable was the piston displacement. During investigations, the piston displacement and crack tip opening data were registered. Test data were collected from the applied load and the clip gauge displacement and were recorded electronically and stored on the computer.

After loading, the specimens were marked by heat tinting in a chamber at $250^{\circ} \mathrm{C}$ for an hour. Following that they were broken open and the fracture surfaces and different types of crack length were examined at 9 locations (see numbers $1 \ldots 9$ in Fig. 4).

\section{Test results}

The recorded data for the investigated HAZs of S960M material grade showed a maximum force plateau on the load - CTOD diagram, see Fig. 5.

In order to determine the $C T O D$ value $\left(\delta_{0}\right)$, the original crack length $a_{0}$, and any stable crack extension, $\Delta a$ that may have occurred during the test have to be measured on 9 locations on the fracture surfaces (see Fig. 4 on the left hand side). The identification of different crack types on the fracture surfaces was not unambiguous. The typical 


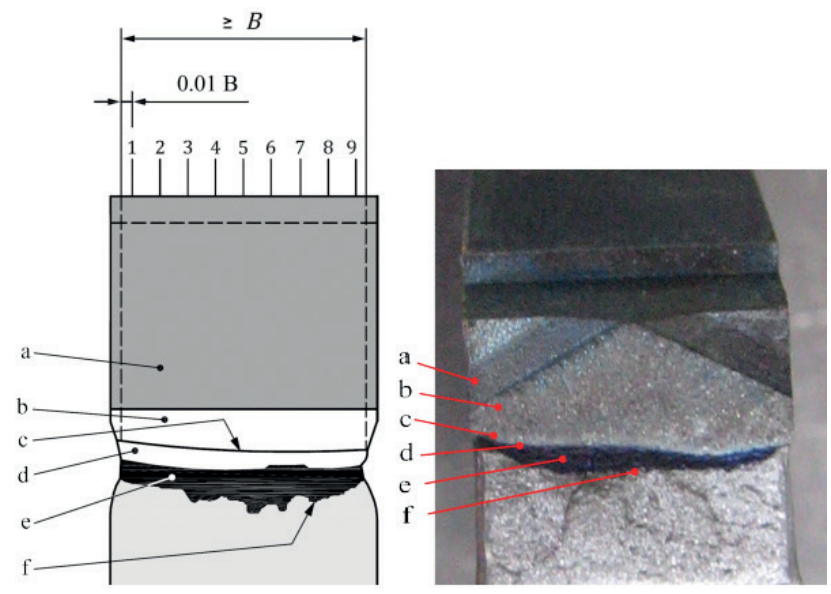

Fig. 4 Measurement of different crack length on the fracture surface according to ISO 12135; ( a) machined notch, b) fatigue precrack, c) initial crack front, d) stretch zone, e) crack extension, f) final crack front)

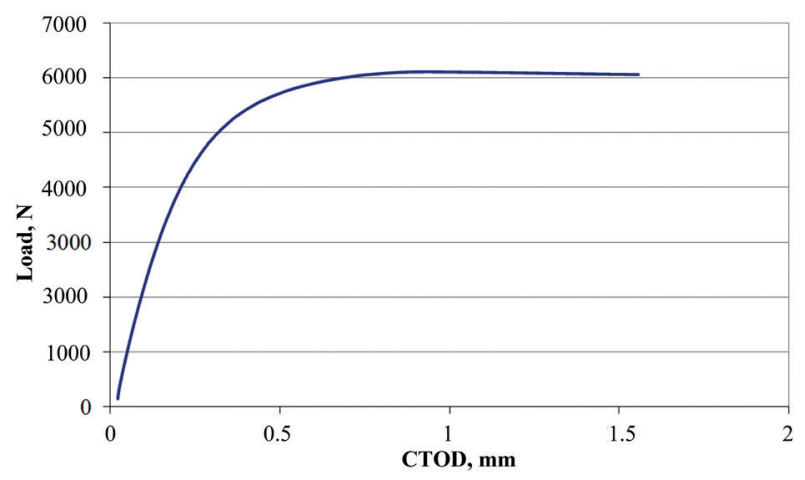

Fig. 5 Typical load - CTOD diagram showing maximum phenomenon

lines for fatigue crack extension during the different loads could not be identified, furthermore no stretch zone could be realized on the fracture surface. The stable crack extension was marked significant after heat tinting, thus the final crack length could be measured accurately.

The CTOD value was calculated applying the formula [11] given by Eq. (1):

$$
\begin{aligned}
\delta_{0}= & {\left[\frac{S}{W} \cdot \frac{F}{\left(B B_{N} W\right)^{0.5}} \cdot g_{1}\left(\frac{a_{0}}{W}\right)\right]^{2} } \\
& \frac{1-v^{2}}{2 Y S \cdot E}+\frac{0.4\left(W-a_{0}\right)}{0.6 a_{0}+0.4 W+z} \cdot V_{p},
\end{aligned}
$$

where

$S:$ span, mm;

$W$ : specimen width, $\mathrm{mm}$ (nominally $10 \mathrm{~mm}$ );

$F$ : applied load, N;

$B$ : specimen thickness, $\mathrm{mm}$ (nominally10 $\mathrm{mm}$ );

$B_{N}$ : specimen net thickness between side grooves, mm;

$g_{1}$ : geometry function given in standard [11]; $a_{0}:$ initial crack length, $\mathrm{mm}$;

$v$ : Poisson's ratio, -;

$Y S$ : Yield strength, $\mathrm{MPa}$;

$E$ : modulus of elasticity, GPa;

$z$ : the initial distance of the notch opening gauge measurement position from the notched edge of the specimen, $\mathrm{mm}$;

$V_{p}$ : plastic component of $\mathrm{V}, \mathrm{mm}$.

When the test record exhibits a maximum force plateau prior to fracture without significant prior pop-ins (sudden increase in force followed by sudden decrease), values of $F_{m}$ and $V_{m}$ shall be obtained from the test recorded at the point corresponding to the first attainment of the maximum force.

3-3 result are available for the simulation with one heating-cooling cycle, however during the fracture mechanical investigations some unexpected circumstances occurred, therefore only 2-2 result could be evaluated for simulations with double heating cycle. The results of fracture mechanical investigations and calculations are given in Table 2. The qualification of $\delta_{0}$ fracture toughness is in every investigated case $\delta_{m}$. In the last column of Table 2 the mean CTOD values of differently simulated HAZ are given. According to these values it can be stated that there is no unambiguous tendency between the $t_{8.5 / 5}$ cooling times and the CTOD values for one heating cycle and nor for double heating cycle. The lowest $\delta_{m}$ values belong to $t_{8.5 / 5}=5 \mathrm{~s}$ cooling time, in both cases. The highest $\delta_{m}$ values

Table 2 CTOD values of different simulated HAZ areas

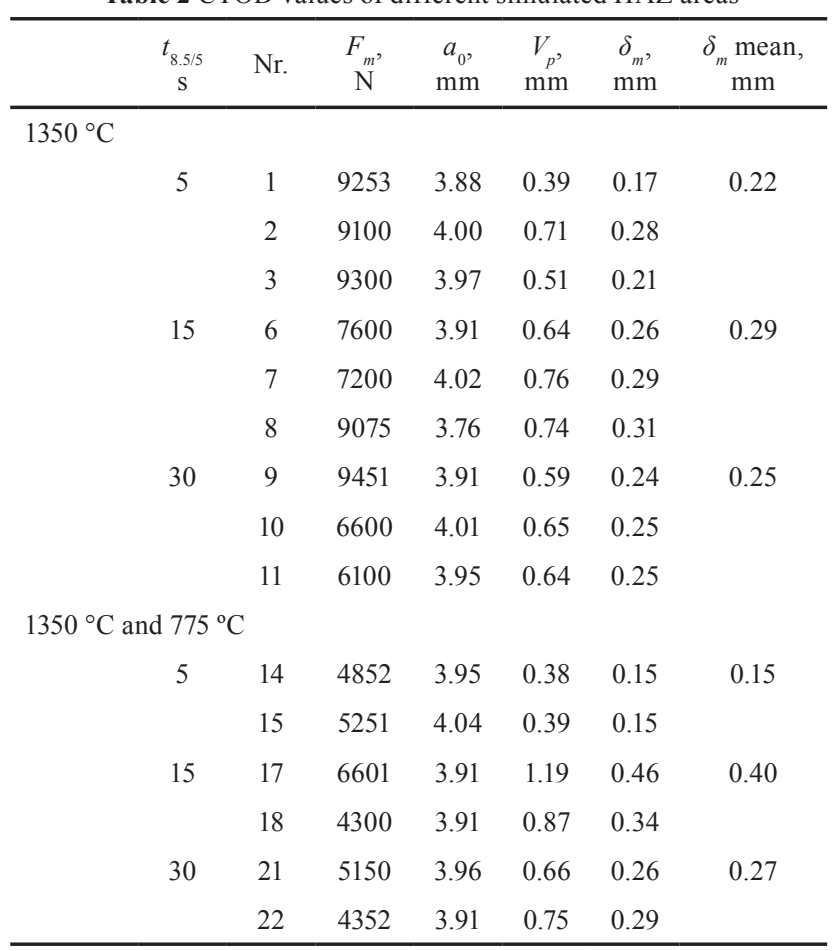


belong surprisingly not to $t_{8.5 / 5}=30 \mathrm{~s}$, but to $\mathrm{t} t_{8.5 / 5}=15 \mathrm{~s}$ cooling time, in both cases. Concluding all the evaluated results, it can be stated, that the $\delta_{m}$ values do not differ significantly applying different simulation methods.

However, the fracture mechanical investigation, the three-point bending test, takes only some minutes, if the total time is summarized with sample preparation and the measurements and evaluation after the test, the fracture mechanical analyses of one specimen takes $1.5 \ldots 2$ days. Furthermore, the machining of a high strength steel is an expensive process. Due to the long investigation time and the higher cost of sample preparation it is advantageous to give reliable results from only a few specimens. The reliability is increased with the control calculation following the investigations given in the standard [11].

For the given investigation, the requirements are fulfilled for the following parameters: specimen geometry, surface roughness, accuracy and reliability of the testing machine, the value of stress intensity factor of fatigue precracking.

The requirements are not fulfilled or only partially fulfilled for the following parameters: all parts of the fatigue precrack have extended at least $1.3 \mathrm{~mm}$ or $2.5 \%$ of $W$, whichever is greater, from the root of the machined notch (this value is generally smaller in our case); none of the seven interior final crack length measurements differs by more than $0.1\left(a_{0}+\Delta a\right)$ from the nine-point average final crack length (this value is changing in our case).

\section{Discussion}

Since there are already measured data available for base material at room temperature for fracture mechanical behavior, it is possible to compare the results with the results measured for the HAZs.

Different investigation parameters can be considered, to have a wider impression about the properties.

The first parameter could be a maximum load, which was necessary for the initiation of crack propagation during the fatigue precracking stage. In case of the base material a maximum force was $8560 \mathrm{~N}$, while in case of the HAZ specimens only $3160 \mathrm{~N}$.

During the fracture mechanical three-point bending tests the suffered maximum load was significant (almost three times higher in case of base material specimens), $26000 \ldots 30000 \mathrm{~N}$ for base material and $4300 \ldots 9500 \mathrm{~N}$ for HAZ specimens.

The mean stable crack extension during the three-point bending tests was smaller for the base material's specimens, $0.3 \mathrm{~mm}$, while for the HAZ specimens $0.46 \mathrm{~mm}$.
The recorded diagrams during the fracture mechanical three-point bending tests were also different, see Fig. 6 .

In case of base material's specimens pop-in phenomenon could be identified for several measurements. In these cases, the $\delta$ value was under $0.2 \mathrm{~mm}$, and its index was $\delta_{c}$. In cases, when the recorded diagram showed maximum force plateau, the value of $\delta$ was over $0.2 \mathrm{~mm}$, and its index was $\delta_{m}$. In case of HAZ specimens only diagrams with maximum force plateau could be recorded, where the value of $\delta$ was over $0.2 \mathrm{~mm}$, and its index was $\delta_{m}$.

All these mentioned behaviors led to a conclusion that no decrease in toughness could be observed, the specimens of HAZ showed more tough behavior than the specimens of the base material.

Further interesting behavior could be analyzed on the fracture surfaces of the specimens, see Fig. 7. On the fracture surface of the base material wider and smaller straight holes can be seen, oriented in one direction, it seems like if the microstructure would contain pancake-like structure-elements. This behavior is not visible on the fracture surfaces of HAZ, but it has to be considered, that the whole specimen was heat treated by Gleeble simulator.

\section{Summary}

The present paper represents results of physical simulation experiments on the HAZ of S960M advanced high strength structural steel. In the Gleeble 3500 simulator the applied peak temperature was $1350^{\circ} \mathrm{C}$ furthermore with an additional tempering temperature of $775{ }^{\circ} \mathrm{C}$, the adjusted $t_{8.5 / 5}$ cooling times changed among $5 \mathrm{~s}, 15 \mathrm{~s}$ and $30 \mathrm{~s}$, appropriate to GMAW parameters.

Common fracture toughness values are not simple to determine, due to the ductile behavior of high strength steels. Based on these properties crack-tip opening dis-

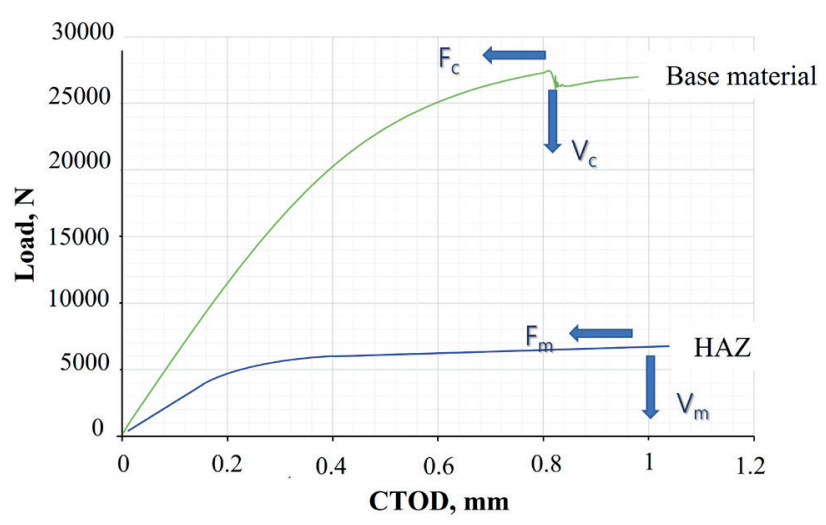

Fig. 6 Comparison between the typical recorded load - CTOD diagram for base material and HAZ specimens 


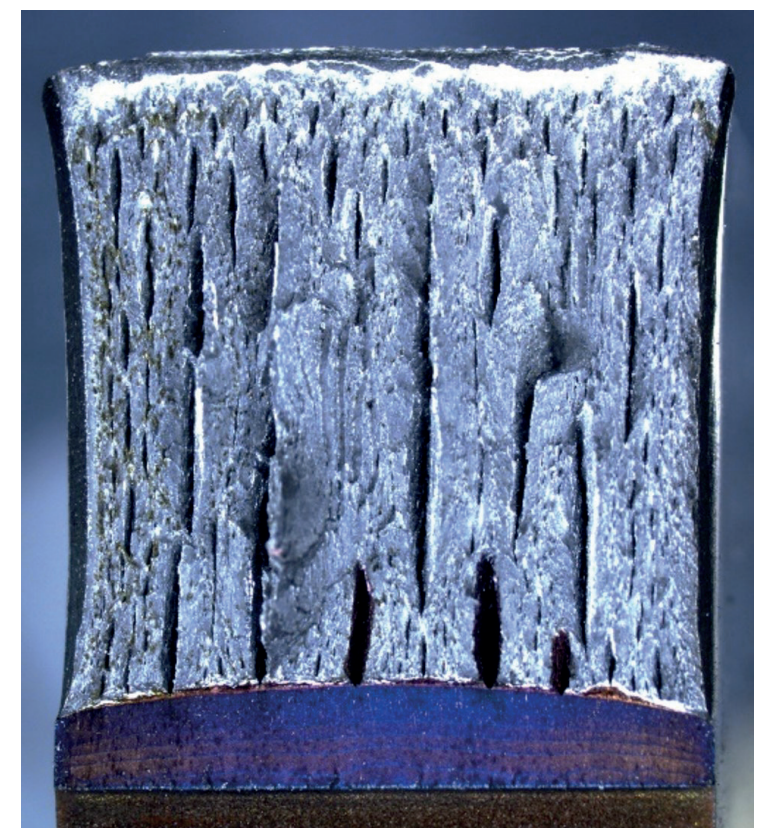

(a)

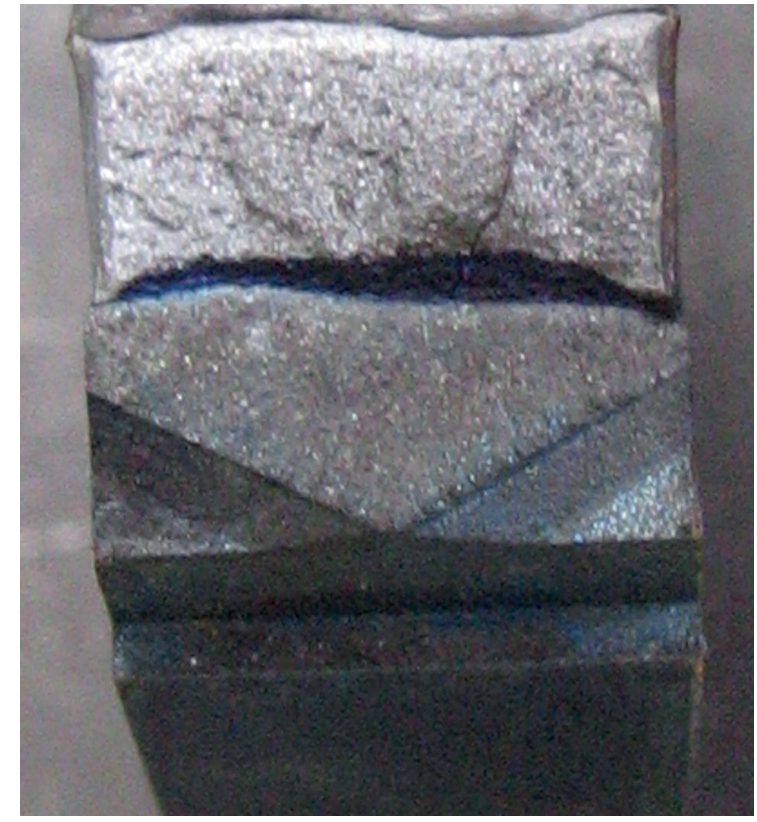

(b)

Fig. 7 Fracture surfaces of base material (a) and typical HAZ (b) specimen

placement $(C T O D$ or $\delta$ ) values were characterized on the simulated HAZs, according to the ISO standard [11]. The $\delta_{0}$ values were calculated, but no unambiguous conclusion could be drawn for the different simulated heat affected zones. However, it can be concluded, that all the registered load-crack tip opening displacement diagrams showed a maximum force plateau, and a $\delta_{m}$ characteristic measure could be determined.

\section{References}

[1] Dobosy, Á., Lukács, J. "The effect of welding parameters on the properties of thermomechanically rolled high strength steels", presented at MultiScience - XXX. microCAD International Multidisciplinary Scientific Conference, Innovative Mechanical Design and Technology Symposium, Miskolc, Hungary, April, 21-22, 2016. https://doi.org/10.26649/musci.2016.079

[2] Willms, R. "High strength steel for steel constructions", In: Nordic Steel Construction Conference 2009, Malmö, Sweden, 2009, pp. 597-604.

[3] Májlinger, K., Borók A., Pasquale, R. S., Varbai, B. "TIG welding of advanced high strength steel sheets", [pdf] In: 4th International Scienific Conference on Advances in Mechanical Engineering (ISCAME 2016), Debrecen, Hungary, 2016, pp. 313-318. Available at: http://real.mtak.hu/84164/1/ISCAME_2016_Proceedings-Spena. pdf [Accessed: 23 November 2021]

[4] ESTEP "Strategic Research Agenda (SRA)", [pdf] European Steel Technology Platform, Brussels, Belgium, Available at: https:// www.estep.eu/assets/SRA-Update-2017Final.pdf [Accessed: 31 December 2020]
Compared the results with the base material properties it can be stated that no decrease in toughness could be observed in the specimen prepared for HAZ.

\section{Acknowledgement}

This research was supported by the Hungarian Higher Education Excellence Programme (FIKP).

In memoriam Dr. Gyula Nagy.

[5] Nobuo, S., Shinji, M., Shigeru, E. "Recent Development in Microstructural Control Technologies through the ThermoMechanical Control Process (TMCP) with JFE Steel's HighPerformance Plates", JFE Steel Corporation, Japan, Rep. 11, 2008.

[6] Toyosada, M. "Characteristics of TMCP steels and their welded joints used for hull structure", In: Proceedings of The Twelfth International Offshore and Polar Engineering Conference, Kitakyushu, Japan, 2002, pp. 385-391.

[7] Tatsumi, K., Kouki, Y., Hidemi, A. "Development of High Strength H-Shapes with Excellent Toughness Manufactured by Advanced Thermo-Mechanical Control Process (TMCP)", JFE Steel Corporation, Japan, Rep. 16. 2011.

[8] Mandzej, S. T. "Physical simulation of metallurgical processes", Materials and Technology, 44(3), pp. 105-119, 2010.

[9] Koncsik, Zs., Fótos, R., Lukács, J. "A fizikai szimuláció és alkalmazása az anyagtechnológiákban" (The physical simulation and its application in materials technologies), In: Pokorádi, L. (ed.) Műszaki Tudomány az Észak-kelet Magyarországi Régióban, Nyíregyháza, Hungary, 2012, pp. 211-217. (in Hungarian) 
[10] Balogh, A., Lukács, J., Török I. "Hegeszthetőség és a hegesztett kötések tulajdonságai: Kutatások járműipari acél és alumíniumötvözet anyagokon" (Weldability and properties of welded joint: Research activities on steel and aluminium alloys for vehicle industry), Miskolci Egyetem, Miskolc, Hungary, 2015. (in Hungarian)

[11] ISO "ISO 12135:2016 Metallic materials - Unified method of test for the determination of quasistatic fracture toughness", International Organization for Standardization, Geneva, Switzerland, 2016.

[12] Gáspár, M. G. "Nemesített nagyszilárdságú szerkezeti acélok hegesztéstechnológiájának fizikai szimulációra alapozott fejlesztése" (Development of welding technology of quenched and tempered high strength steels based on physical simulation), [pdf] PhD thesis, University of Miskolc, 2016. (in Hungarian) Available at: http://midra.uni-miskolc.hu/document/24084/19474.pdf [Accessed: 23 November 2021]

[13] Jámbor, P. "Termomechanikusan kezelt nagyszilárdságú acél hegeszthetőségének fizikai szimulációra alapozott elemzése" (Analyses of weldability of termomechanically treated high strength steel based on physical simulation), [pdf] MSc Thesis, University of Miskolc, 2016. (in Hungarian) Available at: http:// midra.uni-miskolc.hu/document/25434/20668.pdf [Accessed: 23 November 2021]

[14] Gáspár, M. "Nemesített nagyszilárdságú acélok hőhatásövezeti zónáinak előállítása szimulált hegesztési hőciklusok segítségével" (Preparation of heat affected zones of quenched and tempered high strength steels applying simulated welding heat cycles), [pdf] Multidiszciplináris Tudományok, 3(1), pp. 27-38. 2013. (in Hungarian) Available at: https://ojs.uni-miskolc.hu/index.php/ multi/article/view/10 [Accessed: 23 November 2021]

[15] Gáspár, M. "Effect of Welding Heat Input on Simulated HAZ Areas in S960QL High Strength Steel", Metals, 9(11), Article No. 1226, 2019 https://doi.org/10.3390/met9111226

[16] Sisodia, R. P. S., Gáspár, M. "Physical Simulation-based Characterization of HAZ Properties in Steels. Part 1. HighStrength Steels and their Hardness Profiling", Strength of Materials, 51(3), pp. 490-499, 2019.

https://doi.org/10.1007/s11223-019-00094-5

[17] Gáspár, M., Sisodia, R. P. S., Dobosy, A. "Physical Simulationbased Characterization of HAZ Properties in Steels. Part 2. Dualphase Steels", Strength of Materials, 51(5), pp. 805-815, 2019. https://doi.org/10.1007/s11223-019-00128-y

[18] Kovács, J., Sisodia, R. P. S., Gáspár, M. "Hőhatásövezeti zónák fizikai szimulációja nagy szilárdságú szerkezeti acélok esetén" (Physical simulation of heat affected zones in case of high strength zones), Multidiszciplináris Tudományok, 9(4), pp. 152-166, 2019. (in Hungarian) https://doi.org/10.35925/j.multi.2019.4.13

[19] Djahnit, A., Koncsik, Zs. "Analysing the Softening of S960M by Physical Simulation", presented at MultiScience - XXXI. microCAD International Multidisciplinary Scientific Conference, Miskolc, Hungary, April, 20-21, 2017.

https://doi.org/10.26649/musci.2017.077
[20] Lukács, J., Dobosy, Á., Gáspár, M. "Fatigue Crack Propagation Limit Curves for S690QL and S960M High Strength Steels and their Welded Joints", Advanced Materials Research, 1146, pp. 44-56, 2018.

https://doi.org/10.4028/www.scientific.net/AMR.1146.44

[21] Koncsik, Zs., Nagy, Gy., Lukács, J. "COD assessment of S960M grade steel at different temperatures", In: 72nd IIW Annual Assembly and International Conference: Proceedings of International Conference, Prague, Czechia, 2019, Paper ID: IIWDOC X-1958-19.

[22] Koncsik, Zs. "Lifetime analyses of S960M steel grade applying fatigue and fracture mechanical approaches", In: Proceedings of the 1st International Conference on Engineering Solutions for Sustainable Development (ICESSD 2019), Miskolc, Hungary, 2019, pp. 316-324.

[23] Koncsik, Zs., Lukács Zs. "Fracture mechanical analyses of high strength steels applying experiments and simulation", IOP Conference Series: Materials Science and Engineering, 903, Article No. 2020. https://doi.org/10.1088/1757-899X/903/1/012013

[24] Maclar, D. M. "Comparative analyses about the quasi-static fracture mechanical properties of high strength steels by testing and numerical simulation", MSc Thesis, University of Miskolc, 2018. [online] Available at: http://midra.uni-miskolc.hu:80/?docId=29772 [Accessed: 23 November 2021]

[25] Minami, F., Toyoda, M., Thaulow, C., Hauge, M. "Effect of strength mis-match on fracture mechanical behavior of HAZ-notched weld joint", Journal of Japan Welding Society, 13(4) pp. 508-517, 1995. https://doi.org/10.2207/qjjws.13.508

[26] Hadley, I., Pisarski, H. "Materials properties for Engineering Critical Assessment: Background to the advice given is BS 7910:2013", International Journal of Pressure Vessels and Piping, 168, pp. 191-199. 2018.

https://doi.org/10.1016/j.ijpvp.2018.10.016

[27] Hudák, B. "Nagyszilárdságú acélok törésmechanikai vizsgálatai" (Fracture mechanical investigation of high strength steels), MSc Thesis, University of Miskolc, 2019. (in Hungarian) [online] Available at: http://midra.uni-miskolc.hu:80/?docId=31109 [Accessed: 23 November 2021]

[28] Voestalpine Anarbeitung GmbH "Werkzeugnis" (Manufacturer self-certification Official title of the certifitaion), Delivery Note Nr.: 4117479/21. 11., 2014. (in German)

[29] Gleeble "Gleeble Users Training - Gleeble Systems and Applications", Dynamic Systems Inc., Postenkill, NY, USA, 2011.

[30] Gáspár, M., Balogh, A., Sas, I. "Physical simulation aided process optimisation aimed sufficient HAZ toughness for quenched and tempered AHSS", presented at IIW 2015 International Conference Programme, High Strength Steels - Challenges and Applications, Helsinki, Finland, July, 2-3, 2015.

[31] Gáspár, M., Balogh, A. "Fizikai szimulátorral elóállított S960QL hőhatásövezeti sávok szívósságának elemzése műszerezett ütővizsgálatok segítségével" (Toughness analyses of heat affected zones prepared by physical simulator of S960QL by impact notch test), Hegesztéstechnika, 26(4), pp. 51-64. 2015. (in Hungarian)

[32] Rykalin "Teplovüe processzi pri szvarke" (Thermal processes during welding) Publication of the USSR Academy of Sciences, Moscow, Russia, 1953. (in Russian) 